E3S Web of Conferences 1, 04009 (2013)

DOI: $10.1051 / \mathrm{e} 3$ sconf/20130104009

(C) Owned by the authors, published by EDP Sciences, 2013

\title{
Effect of wheat (Triticum aestivum L.) rhizosphere on fractionations of copper in some sewage sludge amended soils
}

\author{
$\underline{\text { H. R. Motaghian }}^{1}$ and A. R. Hosseinpur ${ }^{2}$ \\ ${ }^{1}$ Soil Science Department, Faculty of Agriculture, Shahrekord University, P.O. Box 115, Shahrekord, Iran, \\ hrm_61@yahoo.com \\ ${ }^{2}$ Soil Science Department, Faculty of Agriculture, Shahrekord University, P.O. Box 115, Shahrekord, Iran, \\ hosseinpur-a@agr.sku.ac.ir
}

\begin{abstract}
Our purpose was to quantify the effect of rhizosphere processes on the fractions of Copper $(\mathrm{Cu})$ in 10 soils amended with sewage sludge under greenhouse conditions by using a rhizobox. For amended soils, 1\% $(\mathrm{w} / \mathrm{w})$ of sewage sludge was added to soil samples and then amended soils were incubated at field capacity, for 1 month. After incubation, soils were put in rhizobox and seeds of wheat were planted. Plants were harvested after 8 weeks and rhizosphere and bulk soils were separated. Fractions of $\mathrm{Cu}$ in the rhizosphere and bulk soils were determined. The results showed that $\mathrm{Cu}$ extracted using several extractants in rhizospheric soils were significantly $(\mathrm{P}<0.01)$ lower than in bulk soils. In the rhizosphere of amended soils the average of residual $\mathrm{Cu}$, $\mathrm{Cu}$ associated with iron-manganese oxides, $\mathrm{Cu}$ associated with organic matter, $\mathrm{Cu}$ associated with carbonates and exchangeable $\mathrm{Cu}$ were 18.8, 2.10, $1.00,0.37$ and $0.24 \mathrm{mg} \mathrm{kg}^{-1}$ respectively, whereas above fractions in the bulk soils were $18.1,2.43,0.80,0.42$ and $0.30 \mathrm{mg} \mathrm{kg}^{-1}$ respectively. This study illustrated that $\mathrm{Cu}$-fractions in the wheat rhizosphere were different compare to bulk soils in sewage sludge amended soils.
\end{abstract}

Key words: Copper; Rhizosphere; Sewage sludge; $\mathrm{Cu}$-fractions

\section{Introduction}

Rhizosphere is commonly defined as the zone where root activity influences significantly the biological and chemical properties of the soil (Zoysa et al., 1999). The conditions at the rhizosphere are considerably different from those existing some distance from the root system (Nye, 1981). For this reason many researchers have focused on this zone in addressing issues concerning metal fractionation and bioavailability using various kinds of cultivation devices (Youssef and Chino, 1989; Wang et al. 2001; Tao et al. 2003).

Application of sewage sludge to agricultural soils has many advantages, which include providing a whole array of nutrients for plant growth (e.g., micronutrients and organic matter), increasing beneficial soil organisms, reducing the need for fertilizers and pesticides, and improving soil physical and biological properties ( $\mathrm{Su}$ and Wong, 2003). Land application of sewage sludge has been limited by its enriched heavy metal contents including $\mathrm{Cu}$ (McCartney et al. 2001). In order to evaluate the amount of copper in the soils amended with sewage sludge, it is essential to understand its bioavailability which depends on its form in the soil, rather than on the total amount accumulated (Allen, 1997).

The dependence of metal bioavailability on its chemical speciation is well documented. On the other word, the complexity of the soil-plant relationship may induce changes in the properties of the soil rhizosphere, consequentially the metal fractions in it (Levesque and Mathur, 1986). Some of researcher investigated the effect of rhizosphere on Cu-availability. Wang et al. (2002) stated that fractionation differences were observed for $\mathrm{Cu}$ between the wheat (Triticum aestivum L.) rhizosphere and bulk soil. Tao et al. (2003) investigated chemical forms of $\mathrm{Cu}$ in the rhizosphere and bulk soil of maize plant using rhizobox cultivation and sequential extraction techniques. Their results demonstrated that there were continuous changes in $\mathrm{Cu}$ fractions within the maize rhizosphere. This study was conducted to evaluate fractions of $\mathrm{Cu}$ in bulk and rhizosphere amended soils with sewage sludge.

\section{Materials and Methods}

Ten soil samples were collected from Chaharmahal-VaBakhtiari province, in central Iran. Particle size 
Table 1. Selected properties of studied soils

\begin{tabular}{|c|c|c|c|c|c|c|c|c|c|}
\hline \multirow{2}{*}{ Soil No. } & clay & silt & $\mathrm{CaCO}_{3}$ & $\mathrm{OC}$ & \multirow{2}{*}{$\mathrm{pH}$} & \multirow{2}{*}{$\begin{array}{c}\mathrm{EC} \\
\left(\mathrm{dS} \mathrm{m} \mathrm{m}^{-1}\right)\end{array}$} & \multirow{2}{*}{$\begin{array}{c}\text { CEC } \\
\left(\mathrm{cmol}_{\mathrm{c}} \mathrm{kg}^{-1}\right)\end{array}$} & \multirow{2}{*}{$\begin{array}{l}\text { Available } \mathrm{Cu} \\
\left(\mathrm{mg} \mathrm{kg}^{-1}\right)\end{array}$} & \multirow{2}{*}{$\begin{array}{l}\text { Total Cu } \\
\left(\mathrm{mg} \mathrm{kg}^{-1}\right)\end{array}$} \\
\hline & \multicolumn{4}{|c|}{$(\%)$} & & & & & \\
\hline 1 & 55 & 40 & 28.7 & 0.72 & 7.8 & 0.13 & 20.9 & 1.18 & 24 \\
\hline 2 & 53 & 44 & 35.6 & 0.30 & 8.1 & 0.13 & 19.3 & 1.50 & 23 \\
\hline 3 & 49 & 39 & 29.4 & 0.51 & 7.9 & 0.12 & 22.5 & 0.86 & 19 \\
\hline 4 & 46 & 42 & 26.4 & 0.71 & 7.8 & 0.14 & 21.6 & 1.12 & 18 \\
\hline 5 & 41 & 42 & 32.2 & 0.54 & 8.1 & 0.13 & 16.0 & 1.07 & 18 \\
\hline 6 & 37 & 44 & 32.5 & 0.80 & 7.6 & 0.16 & 15.6 & 0.85 & 17 \\
\hline 7 & 25 & 33 & 41.0 & 0.47 & 7.7 & 0.21 & 11.5 & 0.54 & 15 \\
\hline 8 & 38 & 55 & 23.1 & 1.19 & 8.1 & 0.24 & 17.9 & 1.30 & 21 \\
\hline 9 & 48 & 46 & 11.3 & 1.16 & 7.8 & 0.25 & 18.5 & 0.89 & 21 \\
\hline 10 & 49 & 46 & 14.8 & 0.97 & 7.9 & 0.23 & 17.9 & 1.41 & 25 \\
\hline
\end{tabular}

Available $\mathrm{Cu}: \mathrm{Cu}$ extracted using DTPA-TEA.

distribution, Electrical conductivity (EC), $\mathrm{pH}$, Organic carbon, equivalent calcium carbonate and cation exchange capacity were determined by standard methods. Total and available $\mathrm{Cu}$ was determined using $4 \mathrm{M} \mathrm{HNO}_{3}$ (Sposito et al. 1982) and DTPA-TEA (Lindsay and Norvell, 1978) respectively.

Value of $\mathrm{pH}$ in sewage sludge was 7.5. Electrical conductivity was $2.25 \mathrm{dS} \mathrm{m}^{-1}$. Amount of organic carbon was $38 \%$. Also, the available and total concentrations of $\mathrm{Cu}$ were 41 and $78 \mathrm{mg} \mathrm{kg}^{-1}$, respectively.

A homemade rhizobox (Wang et al. 2001) was used to plant wheat. The dimension of the rhizobox was $200 \mathrm{~mm} \times 130 \mathrm{~mm} \times 200 \mathrm{~mm}$ (length $\times$ width $\times$ height $)$. The rhizobox was divided into three sections: a central zone or rhizosphere zone $(30 \mathrm{~mm}$ in width), which was surrounded by nylon cloth (300 mesh), and left and right nonrhizosphere zones (bulk soil) (50 $\mathrm{mm}$ in width). One percentage $(\mathrm{w} / \mathrm{w})$ of sewage sludge was added to soils, and then amended soils were incubated at field capacity, for 1 month. After incubation, soils were air-dried. Three seeds were sown per rhizosphere zone. Plants were grown under greenhouse conditions. The aboveground parts of the plants were first harvested as shoots. The rhizobox was then dismantled. The rhizosphere soil was sieved gently to remove the roots by keeping the root mass intact as much as possible. The soils taken from rhizosphere soil zone and two bulk soil zones of the left and right were mixed separately for further analysis.

In the bulk and the rhizosphere soils exchangeable $\mathrm{Cu}(\mathrm{EXCH}-\mathrm{Cu}), \mathrm{Cu}$ associated with carbonates (CARB$\mathrm{Cu}$ ), $\mathrm{Cu}$ associated with manganese-iron oxides (OXIDS$\mathrm{Cu}$ ) and $\mathrm{Cu}$ associated with organic matter fractions $(\mathrm{OM}-\mathrm{Cu})$ were determined based on that employed by Tessier et al. (1979) and residual fraction (RES-Cu) was determined using $4 \mathrm{M} \mathrm{HNO}_{3}$ (Sposito et al. 1982).

The significant differences of cu fractions, between rhizosphere and bulk soils were determined by using paired-samples t-test.

\section{Results and Discussion}

Selected chemical and physical properties of the studied soils are shown in Table 1 . These results showed that there was a wide variation in the selected chemical and physical properties of the soils. Clay contents in all soils averaged 44 and ranged from 25 to $55 \%$. The soils were alkaline and low in EC and organic matter. The OC ranged from 0.30 to $1.19 \%$. The equivalent calcium carbonate contents varied from 11.3 to $41.0 \%$. The CEC ranged from 11.5 to $22.5 \mathrm{cmol}_{\mathrm{c}} \mathrm{kg}^{-1}$. The total $\mathrm{Cu}$ in all soils ranged from 15 to $25 \mathrm{mg} \mathrm{kg}^{-1}$. Available $\mathrm{Cu}$ ranged from 0.54 to $1.50 \mathrm{mg} \mathrm{kg}^{-1}$.

The results of the sequential extraction are presented in Table 4. The distribution of various fractions of $\mathrm{Cu}$ was similar for wheat rhizosphere and bulk soils. In the rhizosphere soils the mean of RES-Cu, OXIDS-Cu, OM$\mathrm{Cu}, \mathrm{CARB}-\mathrm{Cu}$ and $\mathrm{EXCH}-\mathrm{Cu}$ were 18.8 (83.54\% of total), 2.10 (9.33\% of total), 1.00 (4.43\% of total), 0.37 (1.64\% of total), and $0.24\left(1.06 \%\right.$ of total $\mathrm{mg} \mathrm{kg}^{-1}$ respectively, whereas in the bulk soils the mean of above $\mathrm{Cu}$-fractions were 18.1 (82.23\% of total), 2.43 (10.91\% of total), 0.80 (3.61\% of total), 0.42 (1.90\% of total) and $0.30(1.35 \%$ of total $) \mathrm{mg} \mathrm{kg}^{-1}$ respectively. Sequential extraction or fractionation of $\mathrm{Cu}$ in soils is a useful technique for determining chemical forms of $\mathrm{Cu}$ in soils. Such information is potentially valuable for predicting bioavailability in agricultural and polluted soils (Tao et al. 2003). The results of table 5 showed that concentrations of $\mathrm{Cu}$-fractions in the rhizosphere were significantly $(\mathrm{P}<0.05)$ different from concentrations of $\mathrm{Cu}$-fractions in the bulk soils. In sewage sludge amended soils, the $\mathrm{Cu}$ associated with organic matter and residual fractions were increased 23.45 and $3.86 \%$ respectively, in the rhizosphere soil. Exchangeable $\mathrm{Cu}, \mathrm{Cu}$ associated with iron-manganese oxides and $\mathrm{Cu}$ associated with carbonate decreased $20.0,13.58$ and $11.90 \%$ respectively, in the rhizosphere soils.

The decrease in exchangeable fraction was also reported by Youssef and Chino (1989). An explanation for the change in exchangeable $\mathrm{Cu}$ is the process of plant uptake (Tao et al., 2003). The exchangeable $\mathrm{Cu}$ may provide some indication of the form of $\mathrm{Cu}$ that is most 
Table 2. $\mathrm{Cu}$ concentration $\left(\mathrm{mg} \mathrm{kg}^{-1}\right)$ in different fractions in the rhizosphere $(\mathrm{R})$ and the bulk (B) soils

\begin{tabular}{|c|c|c|c|c|c|c|c|c|c|c|}
\hline \multirow{2}{*}{ Soil No. } & \multicolumn{2}{|c|}{$\mathrm{EXCH}-\mathrm{Cu}$} & \multicolumn{2}{|c|}{$\mathrm{CARB}-\mathrm{Cu}$} & \multicolumn{2}{|c|}{ OXIDS-Cu } & \multicolumn{2}{|c|}{$\mathrm{OM}-\mathrm{Cu}$} & \multicolumn{2}{|c|}{$\mathrm{RES}-\mathrm{Cu}$} \\
\hline & $\mathrm{R}$ & B & $\mathrm{R}$ & $\mathrm{B}$ & $\mathrm{R}$ & B & $\mathrm{R}$ & $\mathrm{B}$ & $\mathrm{R}$ & B \\
\hline 1 & 0.25 & 0.31 & 0.37 & 0.43 & 2.56 & 3.03 & 1.13 & 0.91 & 23.8 & 21.7 \\
\hline 2 & 0.22 & 0.30 & 0.22 & 0.29 & 2.06 & 2.45 & 0.74 & 0.75 & 20.3 & 19.7 \\
\hline 3 & 0.20 & 0.27 & 0.33 & 0.40 & 1.81 & 2.32 & 0.64 & 0.54 & 17.4 & 16.7 \\
\hline 4 & 0.23 & 0.30 & 0.16 & 0.23 & 2.44 & 2.61 & 1.31 & 0.78 & 17.5 & 17.0 \\
\hline 5 & 0.25 & 0.29 & 0.67 & 0.69 & 1.82 & 1.93 & 0.64 & 0.35 & 16.1 & 15.8 \\
\hline 6 & 0.22 & 0.28 & 0.37 & 0.40 & 1.58 & 2.14 & 0.72 & 0.52 & 16.4 & 14.7 \\
\hline 7 & 0.24 & 0.29 & 0.57 & 0.55 & 1.69 & 1.82 & 0.62 & 0.48 & 13.1 & 12.8 \\
\hline 8 & 0.30 & 0.34 & 0.22 & 0.38 & 2.57 & 2.64 & 1.34 & 1.22 & 19.6 & 19.6 \\
\hline 9 & 0.24 & 0.31 & 0.46 & 0.46 & 2.30 & 2.78 & 1.46 & 1.10 & 19.5 & 18.7 \\
\hline 10 & 0.24 & 0.30 & 0.34 & 0.36 & 2.22 & 2.53 & 1.39 & 1.31 & 24.7 & 24.6 \\
\hline mean & $0.24 b$ & $0.30 \mathrm{a}$ & $0.37 \mathrm{~b}$ & $0.42 \mathrm{a}$ & $2.10 \mathrm{~b}$ & $2.43 \mathrm{a}$ & $1.00 \mathrm{a}$ & $0.80 \mathrm{~b}$ & $18.8 \mathrm{a}$ & $18.1 \mathrm{~b}$ \\
\hline
\end{tabular}

Means in final row for different fractions followed by the different letters are significantly different $(\mathrm{P}<0.05)$.

available for plant uptake (Sparks, 1983). Decrease in the $\mathrm{Cu}$ associated with iron - manganese oxides, can be interpreted by reduction of oxides by organic acid secreted from the plant roots (Godo and Reisenauer, 1980). While the increase in fraction organically bound forms, may be mainly owing to the abundance of organic materials in rhizosphere. Moreover organic matter can redistribute $\mathrm{Cu}$ from soluble and exchangeable forms to $\mathrm{Cu}$ associated with organic matter and the residual fraction (Clemente et al. 2006). Clemente et al. (2006) reported that a humification of sewage sludge organic matter during incubation experiments tended to promote the formation of fulvic acids having a high capacity for $\mathrm{Cu}$ complexation. Such kinds of organic matter may result in slightly increased $\mathrm{Cu}$ availability (Sadovnikova et al. 1996). But the effect of sewage sludge on $\mathrm{Cu}$ mobility will depend also on the organic matter decomposition rate.

\section{Conclusions}

This study illustrated that $\mathrm{Cu}$ fractions were in the order of residual $>$ associated with iron-manganese oxides $>$ associated with organic matter $>$ associated with carbonates $>$ exchangeable in the wheat rhizosphere and bulk soils. Also, the results showed that concentrations of $\mathrm{Cu}$-fractions in the rhizosphere were significantly different from concentrations of $\mathrm{Cu}$-fractions in the bulk soils. The rhizosphere is a small zone but important environmental in soils with quite different chemical properties. The processes involved in the rhizosphere are rather intricacy, and many factors can influence the environmental behaviors of elements in the rhizosphere.

\section{References}

Allen HE. Importance of speciation of metals in natural waters and soils to risk assessment. In: Report of International Workshop on Risk Assessment of Metals and their Inorganic Compounds,
International Council on Metals and the Environment. Ottawa, 1997, pp. 141-157.

Clemente R, Bernal MP. Fractionation of heavy metals and distribution of organic carbon in two contaminated soils amended with humic acids. Chemosphere 2006, 64: 1264-1273.

Godo GH, Reisenauer HM. Plant effect on soil manganese availability. Soil Sci. Soc. Am. J. 1980, 44:993-995.

Levesque MP, Mathur SP. Soil tests for copper, iron and zinc in histosols, 1 . The influence of soil properties, iron, manganese, and zinc on the level and distribution of copper. Soil Sci. 1986, 142: 153-163.

Lindsay WL, Norvell WA. Development of a DTPA soil test for zinc, iron, manganese, and copper. Soil Sci. Soc. Am. J. 1978, 42: 421-428.

McCartney D, Zhang Y, Grant C. Characterization of compost produced at a golf course: impact of historic mercury accumulations in putting green soil. Compost Sci. Util. 2001, 9: 73-91.

Nye PH. Changes of $\mathrm{pH}$ across the rhizosphere induced by roots. Plant Soil, 1981, 61:7-26.

Sadovnikova L, Otabbong E, Iakimenko O, Nilsson I, Persson J, Orlov D. Dynamic transformation of sewage sludge and farmyard manure components, 2Copper, lead and cadmium forms in incubated soils. Agric. Ecosyst. Environ. 1996, 58: 127-132.

Sparks DL. Ion activities: an historical and theoretical overview. Soil Sci. Soc. Am. J. 1983, 48: 514-518.

Sposito G, Lund LJ, Chang A. Trace metal chemistry in arid-zone field soils amended with sewage sludge. I. Fractionation of $\mathrm{Ni}, \mathrm{Cu}, \mathrm{Zn}, \mathrm{Cd}$, and $\mathrm{Pb}$ in solid phases. Soil Sci. Soc. Am. J. 1982, 46:260-264.

$\mathrm{Su}$ DC, Wong JWC. Chemical speciation and phytoavailability of $\mathrm{Zn}, \mathrm{Cu}, \mathrm{Ni}$ and $\mathrm{Cd}$ in soil amended with fly ash-stabilized sewage sludge. Environ. Int. 2003, 29:895-900.

Tao S, Chen FL, Xu J, Cao B, Li G. Changes of copper speciation in maize rhizosphere soil. Environ. Pollut. 2003, 122:447-454. 
Tessier A, Campbell PGC, Bisson M. Sequential extraction procedure for the speciation of particulate trace-metals. Anal. Chem. 1979, 5:844-851.

Wang Z, Shan XQ, Zhang S. Comparison of speciation and bioavailability of rare earth elements between wet rhizosphere soil and air-dried bulk soil. Anal. Chim. Acta. 2001, 44:147-156.

Youssef RA, Chino M. Root-induced changes in the rhizosphere of plants. II. Distribution of heavy metals across the rhizosphere in soils. Soil Sci. Plant Nutr. 1989, 35:609-621.

Zoysa AKN, Loganathan P, Hedley MJ. Phosphorus utilisation efficiency and depletion of phosphate fractions in the rhizosphere of three tea (Camellia sinensis L.) clones. Nutr. Cycl. Agroecosyst, 1999, 53:189-201. 